\title{
Chapter 13 \\ Protection of Animals Through Human \\ Rights: The Case-Law of the European Court of Human Rights
}

\section{Tom Sparks}

\begin{abstract}
The chapter discusses the potential of a human rights framework to contribute to the growth and development of global animal law. It takes as example the jurisprudence of the European Court of Human Rights, and examine the major trends in the Court's judgments and admissibility decisions that directly or indirectly concern the rights or welfare of animals. It is concluded that the Court is not indifferent to the welfare of animals, but that animal welfare is instrumentalised: it is understood not as a good in itself, but is instead valued for its implications for human welfare and rights. The chapter then considers the obstacles that the anthropocentrism of the human rights idea and the instrumentalisation of animal concerns present to the use of human rights frameworks to further the development of global animal law, as well as the opportunities that exist in the meeting of these paradigms. It concludes that although the telos of human rights law is different from that of animal law, nevertheless there exist many overlapping concerns within which mutually beneficial interactions are possible.
\end{abstract}

\section{Introduction}

The institutionalisation of human rights under the regional human rights frameworks has given legal force to an idea already rich in transformative potential. Human rights have become a vital tool in efforts to achieve change both for individuals, and across legal systems. To seek, though, to harness the potential of human rights institutions and discourse to advance animal welfare and animal rights may appear farfetched: one could be forgiven for a certain scepticism concerning the availability of space for animal concerns in this deliberately human-centred area of law and policy. Nevertheless, there are indications of certain modest advances which offer

\footnotetext{
T. Sparks $(\bowtie)$

Max Planck Institute for Comparative Public Law and International Law, Heidelberg, Germany e-mail: sparks@mpil.de

A. Peters (ed.), Studies in Global Animal Law, Beiträge zum ausländischen öffentlichen Recht und Völkerrecht 290, https://doi.org/10.1007/978-3-662-60756-5_13
} 
opportunities for animal welfare and rights concerns to be considered within the framework of human rights.

This chapter will consider the case-law of the European Court of Human Rights (ECtHR) in the field of animal law, and will identify the broad themes and trends within that jurisprudence. The ECtHR has only rarely considered questions either directly or tangentially relevant to the protection of animal rights, but there are nonetheless almost thirty relevant judgments and admissibility decisions, ${ }^{1}$ which will be divided thematically (Sects. 2 and 3 ). ${ }^{2}$ Section 4 will then consider the current legal and conceptual barriers to more effective animal protection under the Convention, and will make some tentative remarks on the potential of the ECHR and its Court (as well as human rights frameworks more broadly) to contribute to the development of global standards on animal welfare.

\footnotetext{
${ }^{1}$ The relevant cases are, in chronological order, ECHR, Steel and Others $v$. UK, Chamber Judgment of 23 September 1998, Application No. 24838/94; ECHR, Chassagnou and Others v. France, Grand Chamber Judgment of 29 April 1999, Applications Nos. 25088/94, 28331/95, and 28443/95; ECHR, Bladet Troms $\phi$ and Stensaas v. Norway, Grand Chamber Judgment of 20 May 1999, Application No. 21980/93; ECHR, Hashman and Harrup v. UK, Grand Chamber Judgment of 25 November 1999, Application No. 25594/94; ECHR, Geert Drieman and Others v. Norway, Third Section Decision on Admissibility of 4 May 2000, Application No. 33678/96; ECHR, Cha'are Shalom Ve Tsedek v. France, Grand Chamber Judgment of 27 June 2000, Application No. 27417/95; ECHR, Verein gegen Tierfabriken v. Switzerland, Second Section Judgment of 28 June 2001, Application No. 24699/94 (VgT No. I); ECHR, Kyrtatos v. Greece, First Section Judgment of 22 May 2003, Application No. 41666/98; ECHR, Piippo v. Sweden, Second Section Partial Decision on Admissibility of 7 December 2004, Application No. 70518/01; ECHR, Steel and Morris v. UK, Fourth Section Judgment of 15 February 2005, Application No. 68416/01; ECHR, Piippo v. Sweden, Second Section Decision on Admissibility of 21 March 2006, Application No. 70518/01; ECHR, Schneider v. Luxembourg, Second Section Judgment of 10 July 2007, Application No. 2113/04; ECHR, Baudinière and Vauzelle v. France, Third Section Decision on Admissibility of 6 December 2007, Application Nos. 25708/03 and 25719/03; ECHR, Nilsson v Sweden, Third Section Decision on Admissibility of 26 February 2008, Application No. 11811/05; ECHR, Verein gegen Tierfabriken Schweiz v. Switzerland (No.2), Grand Chamber Judgment of 30 June 2009, Application No. 32772/02 (VgT No. II); ECHR, Friend and Others v. United Kingdom, Fourth Section Decision on Admissibility of 24 November 2009, Application Nos. 16072/06 and 27809/08; ECHR, Jakóbski v. Poland, Fourth Section Judgment of 7 December 2010, Application No. 18429/06; ECHR, Berü v. Turkey, Second Section Judgment of 11 January 2011, Application No. 47304/07; ECHR, Georgel and Georgeta Stoicescu v. Romania, Third Section Judgment of 26 July 2011, Application No. 9718/03; ECHR, ASPAS and Lasgrezas v. France, Fifth Section Judgment of 22 September 2011, Application No. 29953/08; ECHR, Herrmann v. Germany, Grand Chamber Judgment of 26 June 2012, Application No. 9300/07; ECHR, Chabauty v. France, Grand Chamber Judgment of 4 October 2012, Application No. 57412/ 08; ECHR, PETA Deutschland v. Germany, Fifth Section Judgment of 8 November 2012, Application No. 43481/09; ECHR, Animal Defenders International (ADI) v. UK, Grand Chamber Judgment of 22 April 2013, Application No. 48876/08; ECHR, Tierbefreier e.V. v. Germany, Fifth Section Judgment of 16 January 2014, Application No. 45192/09.

${ }^{2} \mathrm{~A}$ small number of cases fall into neither category, and are briefly mentioned in section three.
} 


\section{The Hunting Cases}

In 1998, the first hunting case came before the Court. Steel and Others concerned a series of individuals arrested for the English common law offence of breach of the peace for acts of protest, and who had been subject to binding over orders. ${ }^{3}$ The protest in the case of the first applicant was the disruption of a grouse shooting party and, following her refusal to accept a binding over order, she was jailed for 28 days. ${ }^{4}$ The Court examined the complaint under the article 5 prohibition on arbitrary deprivation of liberty and as an interference with the applicant's right to free expression (article 10). In finding no violation, it noted that Ms Steel had been subjected to 'serious interferences with the exercise of her right to freedom of expression', ${ }^{5}$ but balanced this against the 'obstruction' of the 'lawful pastime' of the hunting party and the 'risk of disorder' arising therefrom, ${ }^{6}$ as well as the 'importance in a democratic society of maintaining the rule of law and the authority of the judiciary'. ${ }^{7}$ It therefore held that her arrest and detention were not disproportionate interferences with her convention rights. ${ }^{8}$

However, in subsequent cases, the Court has asserted that a moral conviction against hunting is capable of attracting Convention protection, ${ }^{9}$ that animal welfare is a matter of public interest, ${ }^{10}$ and that no Convention protection of the right to hunt exists. ${ }^{11}$ Nevertheless, it remains a mixed practice.

\subsection{Hunting Under Article 1 of Protocol 1}

The 1999 case of Chassagnou v. France concerned ten applicants, each of whom owned land in areas regulated by the Loi Verdeille. Under that law, all landowners whose holdings are below a certain threshold are required to pool their lands for the purposes of creating an area within which members of the relevant municipal

\footnotetext{
${ }^{3}$ ECHR, Steel and Others v. UK (n. 1), paras. 6-24.

${ }^{4}$ Ibid., para. 13.

${ }^{5}$ Ibid., para. 103.

${ }^{6}$ Ibid.

${ }^{7}$ Ibid., para. 107.

${ }^{8}$ Ibid.

${ }^{9}$ ECHR, Chassagnou v. France (n. 1), para. 114; see also ECHR, Schneider v. Luxembourg (n. 1), para. 80; ECHR, Herrmann v. Germany (n. 1), para. 80.

${ }^{10}$ ECHR, Bladet Troms $\phi$ and Stensaas (n. 1), paras. 63-64, 73; see also ECHR, Steel and Morris v. UK (n. 1), para. 88; ECHR, PETA Deutschland v. Germany (n. 1), para. 47; ECHR, VgT No. II (n. 1), para. 92.

${ }^{11}$ ECHR, Chassagnou v. France (n. 1), para. 113; see also ECHR, Nilsson v. Sweden (n. 1), 11.
} 
hunting association (ACCA) may freely hunt. The landowners whose property forms a part of the hunting area are automatically members of the local ACCA. ${ }^{12}$ The applicants in the case were all ethically opposed to hunting, and made unsuccessful applications to have their properties removed from the hunting areas, and themselves released from membership of the ACCAs. ${ }^{13}$ The Court found violations of article 11 (freedom of association) and article 1 of Protocol 1 (protection of property) taken separately, and also found violations of each of these provisions when read in conjunction with the protection from discrimination in the application of the convention (article 14).

The Court accepted that the imposition of ACCA membership and the requirement to permit hunting on the applicants' land pursued a legitimate aim (it commented that 'it is undoubtedly in the general interest to avoid unregulated hunting and encourage the rational management of game stocks'). ${ }^{14}$ Nevertheless, it recognised that the applicants' ethical objections were relevant to the assessment of the proportionality of the interference. In relation to article 1 of Protocol 1 it noted that the Government's characterisation of membership of the ACCA as 'compensation' for the loss of the exclusive right to hunt (or, as the case may be, to choose not to hunt) over one's land 'is valuable only in so far as all the landowners concerned are hunters or accept hunting." 15 It consequently found that '[c]ompelling small landowners to transfer hunting rights over their land so that others can make use of them in a way which is totally incompatible with their beliefs imposes a disproportionate burden'. ${ }^{16}$

Perhaps even more telling was the Court's 2012 judgment in Chabauty v. France, the most recent in a line of cases brought under article 1 of Protocol 1 by hunters. ${ }^{17}$ The applicant challenged the inclusion of his land in the hunting area, but in this case because he wished privately to rent the right to hunt on his land. ${ }^{18}$ The Court found no violation of article 1 of Protocol 1, read in conjunction with article 14, and in so doing expressly distinguished the case from Chassagnou and its line ${ }^{19}$ as a result of the applicant's (lack of) ethical objections to hunting. Absent the conflict of conscience, the decision on how hunting should be regulated fell within the state's

\footnotetext{
${ }^{12}$ ECHR, Chassagnou v. France (n. 1), paras. 13-15, 46.

${ }^{13}$ Ibid., paras. 16-18, 23-24, 28-30.

${ }^{14}$ Ibid., para. 79.

${ }^{15}$ Ibid., para. 82 .

${ }^{16}$ Ibid., para. 85. The Court has subsequently confirmed Chassagnou in ECHR, Schneider v. Luxembourg (n. 1); and ECHR, Herrmann v. Germany (n. 1).

${ }^{17}$ ECHR, Piippo v. Sweden (Second Decision, 2006) (n. 1); ECHR, Nilsson v. Sweden (n. 1); ECHR, Baudinière and Vauzelle v. France (n. 1); and ECHR, Chabauty v. France (n. 1).

${ }^{18}$ Ibid., paras. 12-17.

${ }^{19}$ ECHR, Chassagnou v. France (n. 1); ECHR, Schneider v. Luxembourg (n. 1); ECHR, Herrmann v. Germany (n. 1).
} 
margin of appreciation, and no disproportionate interference with the right to property was found. ${ }^{20}$

As the line of cases culminating in Chabauty shows, this is no reification of the right to property. On the contrary, the Court has been inclined to give the state a wide margin of appreciation to regulate hunting. ${ }^{21}$ Nevertheless, ethical objections to hunting are sufficient significantly to narrow the margin of appreciation, and the Court has consistently held that national regulation of hunting must make provision for the rights of opponents of hunting to use their land in ways that accord with their beliefs. Though this is only a small step towards Convention support for animal concerns, it is nevertheless noteworthy both as a protection for animal rights activists, and because it recognises opposition to hunting (and perhaps by implication concern for animals more broadly) as a politico-moral opinion capable of attracting ECHR protection.

\subsection{Hunting Under Articles 10 and 11}

Articles 10 and 11 have been invoked alongside the right to property as further grounds to find the obligation to accept hunting interferes with the Convention rights of conscientious objectors, ${ }^{22}$ but have also twice been invoked in the separate context of anti-hunting protest. ${ }^{23}$ Here the Court has seemed more reluctant to grant protection: in neither case were the restrictions of the applicants' acts of protest in defence of animal rights considered to be violations of the Convention.

Articles 10 and 11 were first invoked by an anti-hunting protester in Steel and Others $v . U K .^{24}$ The first applicant claimed violations of articles 10 and 11 of the Convention, but only article 10 was considered, ${ }^{25}$ and no violation was found. ${ }^{26}$ The Court emphasised that the applicant's protest—which involved placing herself in front of the hunters to prevent them from firing-'created a danger of serious physical injury to herself and others' and 'risked culminating in disorder and violence. ${ }^{27}$ It appears, therefore, to be the applicant's direct action which justified her arrest and imprisonment, a conclusion reinforced by Geert Drieman and Others

\footnotetext{
${ }^{20}$ Ibid., paras. 41-50, 56-57.

${ }^{21}$ Çoban notes that the Court's general approach to article 1 of Protocol 1 has been to 'favour[] the public interest rather than individual rights.' Çoban, Protection of Property Rights 2004, 257.

${ }^{22}$ ECHR, Chassagnou v. France (n. 1), para. 103, 117; ECHR, Schneider v. Luxembourg (n. 1), paras. 82-83.

${ }^{23}$ ECHR, Steel and Others v. UK (n. 1); ECHR, Drieman and Others v. Norway (n. 1).

${ }^{24}$ ECHR, Steel and Others v. UK (n. 1), paras. 6-13. See also above, sec. 2.1.

${ }^{25}$ The Court decided that it was not necessary to consider the application of article 11 because the complaint did not 'raise[] any issues not already examined in the context of article 10': ECHR, Steel and Others v. $U K$ (n. 1), para. 113.

${ }^{26}$ Ibid., paras. 102-107.

${ }^{27}$ Ibid., para. 105.
} 
v. Norway. Here the applicants were arrested and held on remand for actions taken to disrupt a whale hunt in Norway's exclusive economic zone. ${ }^{28}$ The applicants claimed that their arrest and detention violated articles 10 and 11 of the Convention, and the Court accepted that these actions amounted to an interference. Nevertheless, it decided that the application was manifestly ill founded under article 35(3) of the Convention, and therefore inadmissible. ${ }^{29}$

The decision that the complaint in Drieman was manifestly ill founded and not worthy of further consideration is somewhat surprising, and seems to indicate a hostility to direct action as a form of protest. Though it was accepted by the Court that there had been an interference with articles 10 and 11, it considered it sufficiently obvious that the state's actions were proportionate that a more detailed assessment was manifestly unnecessary. Its reasoning supports two possible (non-exclusive) interpretations: that the applicants' aims did not require protection in a democratic society; or that their methods were sufficiently outrageous that states cannot be required to tolerate such conduct in defence of the right to protest. The first, it seems, played a role. The Court noted that the interference pursued the legitimate aim of 'enforc[ing ...] the rules protecting whaling', ${ }^{30}$ and counterbalanced that remark with a finding that the protest 'forc[ed] the whalers to abandon their lawful activity'. ${ }^{31}$ It noted, too, that the relevant conduct 'could not enjoy the same privileged protection under the Convention as political speech or debate on questions of public interests or the peaceful demonstration of opinions on such matters' ${ }^{32}$ Although this latter comment is more closely tied to the question of methods, taken together these statements indicate the Court's opinion that the subject of the protest did not attract a high standard of protection..$^{33}$ On the contrary,

\footnotetext{
${ }^{28}$ ECHR, Drieman and Others v. Norway (n. 1), 2.

${ }^{29}$ Ibid., 10.

${ }^{30}$ Ibid., 9.

${ }^{31}$ Ibid., 10.

${ }^{32}$ Ibid.

${ }^{33}$ The Court has implied in a series of cases that there is a hierarchy within articles 10 and 11 , wherein certain subjects (those that are "political" or in the "public interest") will receive a higher level of protection than others. See ECHR, Sunday Times v. UK, Grand Chamber Judgment of 26 April 1979, Application No. 6538/74, 29-30; ECHR, Lingens v. Austria, Grand Chamber Judgment of 8 July 1986, Application No. 9815/82, paras. 34-47; ECHR, Thorgeirson v. Iceland, para. 60-70; Chamber Judgment of 25 June 1992, Application No. 13778/88, paras. 55-70; ECHR, Jersild v. Denmark, Grand Chamber Judgment of 23 September 1994, Application No. 15890/89, paras. 25-37; and contrast ECHR, Handyside v. UK, Grand Chamber Judgment of 7 December 1976, Application No. 5493/72, paras. 42-59; ECHR, Wingrove v. UK, Chamber Judgment of 25 November 1996, Application No. 17419/90, paras. 52-64, esp. 58; ECHR, Vereinigung Bildender Künstler v. Austria, First Section Judgment of 25 January 2007, Application No. 68354/01, paras. 26-39.
} 
the Court privileged the economic activity of the whalers over the protest of the animal rights activists. ${ }^{34}$

In its assessment of the methods, too, the Court seemed ill-disposed to the direct action of the protestors. ${ }^{35}$ The comment above contrasting the protestors' actions with 'peaceful demonstration of opinions' on questions of public interest should be read alongside the characterisation of those actions as 'a form of coercion', and 'an ultimatum'. ${ }^{36}$ Yet unlike in Steel and Others there was no suggestion that the applicants' protests had created a danger to the whalers or to any other person ${ }^{37}$; unlike in Kudrevičius and Others the disruption caused to 'activities lawfully carried out by others' did not affect a large number of people, but instead only a small group $^{38}$; and unlike in Taranenko v. Russia the protests did not result in violence. ${ }^{39}$ Nevertheless, the Court in Drieman directly contrasted its approach in cases involving 'the peaceful demonstration of opinions on [matters of public interest]' (in which a narrow margin of appreciation is appropriate) with the facts before it, where it found that '[c]ontracting States must be allowed a wide margin of appreciation in their assessment of the necessity of taking measures to restrict such conduct.' 40

\footnotetext{
${ }^{34}$ In this connection, it is particularly relevant that the Court observed that the protest had been taking place unimpeded for one month, and only when the protestors' activities interfered with the hunt did the authorities take action. See ECHR, Drieman and Others v. Norway (n. 1), 10.

${ }^{35}$ Fenwick et al consider that the findings in Steel and Others and the cases that followed it demonstrate that direct action protests engage article 11 in principle: Helen Fenwick/Gavin Phillipson/Alexander Williams, Texts, Cases and Materials on Public Law and Human Rights (4th ed., Abingdon: Routledge 2017), 999. However, the Court has tended to apply a very wide margin of appreciation in such cases, characterising direct action as 'reprehensible', and implying that it cannot be considered wholly 'peaceful' even when no violent action is taken: Kudrevičius and Others v. Lithuania, Grand Chamber Judgment of 15 October 2015, Application No. 37553/05, paras. 173-174; see also Steel and Others (n. 1); G. v. Germany, Decision by the Commission on Admissibility of 6 March 1989, Application No. 13079/87; Lucas v. UK, Fourth Section Decision on Admissibility of 18 March 2003, Application No. 39013/02; Baracco v. France, Fifth Section Judgment of 5 March 2009, Application No. 31684/05. Nevertheless the Court has held that the margin it grants in such cases 'although wide, is not unlimited' (para. 86), and it has been willing to find that a certain level of criminal sanction (in Taranenko three years' imprisonment) is disproportionate to the aim of preventing illegal protest: ECHR, Taranenko v. Russia, First Section Judgment of 15 May 2014, Application No. 19554/05, paras.81-97.

${ }^{36}$ Ibid., 10.

${ }^{37}$ ECHR, Steel v. Others (n. 1), para. 103.

${ }^{38}$ ECHR, Kudrevičius and Others v. Lithuania (n. 35), paras. 142-184, esp. 169-175.

${ }^{39}$ ECHR, Taranenko v. Russia (n. 35).

${ }^{40}$ Ibid.
} 


\section{Animal Welfare and Freedom of Speech}

Claims under article 10 in the context of hunting have come in parallel to article 11 , in cases concerning protest. There, the articles were considered to raise the same issues. ${ }^{41}$ Freedom of speech has also been invoked separately from the freedom of association, however; both in relation to reporting on hunting, ${ }^{42}$ and publications by animal rights groups. ${ }^{43}$

The first animal welfare case to raise article 10 outwith the context of protest was Bladet Troms $\varnothing$ and Stensaas $v$. Norway. The case was brought by the Bladet Troms $\phi$ newspaper and its editor, following a successful defamation suit against them for articles which reported allegations by a seal hunt inspector of cruel and illegal practices. ${ }^{44}$ Defamation proceedings were brought by the hunters concerned sequentially against the inspector, Bladet Troms $\phi$ and its editor, and (unsuccessfully) against several other media outlets. The Court began its assessment with its familiar assertion of the high importance of the press, and declared that '[i]n cases such as the present one the national margin of appreciation is circumscribed by the interest of democratic society in enabling the press to exercise its vital role of 'public watch$\mathrm{dog}$ ' in imparting information of serious public concern'. ${ }^{45}$ It held too that 'in order to determine whether the interference was based on sufficient reasons which rendered it 'necessary', regard must be had to the public-interest aspect of the case. ${ }^{46}$ This it found to be high, referring to the 'legitimate public concern' with the subject matter, ${ }^{47}$ and noting that it was in actuality 'of evident concern to the local, national and international public'. ${ }^{4}$

The Court's strong declaration that animal welfare and the exposure of cruelty to animals is a legitimate matter of public interest is, in the author's opinion, more significant than the ultimate finding that article 10 had been violated in the circumstances of the case. ${ }^{49}$ The Court has been loath to hold that restrictions on journalistic speech on matters of public interest can be justified except under circumstances of clear abuse, and has repeatedly held that the state's margin of appreciation will be very narrow where the freedom of the press is concerned. ${ }^{50}$ That article 10 was

\footnotetext{
${ }^{41}$ ECHR, Steel and Others (n. 1), paras. 112-113; ECHR, Drieman (n. 1), 7-10.

${ }^{42}$ ECHR, Bladet Troms $\phi$ and Stensaas (n. 1).

${ }^{43}$ ECHR, VgT Nos. I\&II (n. 1); ECHR, Steel and Morris v. UK (n. 1); ECHR, PETA Deutschland v. Germany (n. 1); ECHR, ADI v. UK (n. 1); and ECHR, Tierbefreier e.V. v. Germany (n. 1).

${ }^{44}$ ECHR, Bladet Troms $\phi$ and Stensaas (n. 1), paras. 6-38.

${ }^{45}$ Ibid., para. 59.

${ }^{46}$ Ibid., para. 62.

${ }^{47}$ Ibid., para. 64.

${ }^{48}$ Ibid., para. 63 .

${ }^{49}$ Ibid., para. 73 .

${ }^{50}$ See, for example, the statement by the Court in Thorgeirson that the press has a 'pre-eminent role [...] in a State governed by the rule of law': ECHR, Thorgeirson v. Iceland (n. 33), para. 63. See further, among others, Sunday Times v. UK (n. 33), 33; ECHR, Lingens v. Austria (n. 33), para. 13;
} 
violated was an unsurprising conclusion, therefore, once the finding had been made that a debate on animal cruelty was a matter of public interest: it was the combination of public interest and journalistic speech which was important for the outcome. The same can be said of the subsequent article 10 cases concerning aspects of animal welfare that have come before the Court: for present purposes the ultimate decisions are of secondary importance, being determined primarily by factors not directly relevant to animal welfare. That is significant in itself, however, insofar as it demonstrates that the role given to animal welfare concerns in article 10 cases is a narrow one, limited to determination of the appropriate standard of review.

In the years following Bladet Troms $\varnothing$ and Stensaas the Court has ruled on the application of article 10 in relation to animal welfare in six cases, each of which concerned the legality of restrictions on communications by animal welfare groups either (as in VgT Nos. I\&II and ADI v. UK) relating to the media available to them, ${ }^{51}$ or (as in Steel and Morris, PETA Deutschland and Tierbefreier e.V.) the content of those communications. ${ }^{52}$ In each case the Court reiterated its finding that animal welfare and animal rights are 'topics of general concern', 53 and 'questions of public interest'. ${ }^{54}$ Accordingly, it has repeatedly noted that the margin of appreciation due to states in determining to what extent such communications can be restricted is narrow, ${ }^{55}$ and has even gone so far as to suggest that the standard of protection appropriate to campaigning groups working on such matters is similar (although perhaps not identical) to that applicable to journalists. ${ }^{56}$

ECHR, Oberschlick v. Austria, Grand Chamber Judgment of 23 May 1991, Application No. 1162/ 85, para. 58; ECHR, Observer and Guardian v. UK, Grand Chamber Judgment of 26 November 1991, Application No. 13585/88, para. 59; ECHR, Jersild v. Denmark (n. 33), para. 31; ECHR, Goodwin v. UK, Grand Chamber Judgment of 27 March 1996, Application No. 17488/90, para. 39. These principles have been reaffirmed in the recent case of ECHR, Satakunnan Markkinapörssi Oy and Satamedia Oy v. Finland, Grand Chamber Judgment of 27 June 2017, Application No. 931/13, paras. 124-128.

${ }^{51}$ ECHR, VgT No. I (n. 1), paras. 8-23; VgT No. II (n. 1), paras. 12-27; ECHR, ADI v. UK (n. 1), paras. 8-33.

${ }^{52}$ ECHR, Steel and Morris v. UK (n. 1), paras. 8-36; ECHR, PETA Deutschland v. Germany (n. 1), paras. 6-19; ECHR, Tierbefreier e.V. v. Germany (n. 1), paras. 5-21.

${ }^{53}$ ECHR, Steel and Morris v. UK (n. 1), para. 88.

${ }^{54}$ ECHR, PETA Deutschland v. Germany (n. 1), para. 47. See also ECHR, VgT No.II (n. 1), para. 92.

${ }^{55}$ In VgT No. I the Court noted that 'in the present case the extent of the margin of appreciation is reduced, since what is at state is not a given individual's purely "commercial" interests, but [their] participation in a debate affecting the general interest': ECHR, $\operatorname{Vg} T$ No. $I$ (n. 1), para. 71. See also ECHR, ADI v. UK (n. 1), para. 104.

${ }^{56}$ ECHR, Steel and Morris v. UK (n. 1), para. 89, [references omitted]. 


\section{Obstacles and Opportunities}

Nevertheless, it is abundantly clear from the Courts' reasoning in these and other cases that what is protected is the interest that humans may feel in the welfare and suffering of animals, and not the welfare of animals as an end in itself. The distinction is illustrated particularly clearly in PETA Deutschland v. Germany. That case concerned an advertising campaign which juxtaposed images of mass farming methods with Nazi-era concentration camps, together with text which claimed similarities between the treatment of holocaust victims and treatment of animals in the modern meat industry. One such caption ran 'where animals are concerned everyone becomes a Nazi' ('[w]o es um Tiere geht, wird jeder zum Nazi'). ${ }^{57}$ An injunction was requested by Jewish community leaders, and granted by the domestic Courts on the basis that 'the debasement of concentration camp victims was [...] exploited in order to militate for better accommodation of laying hens and other animals. ${ }^{58}$ Though the courts at all levels noted that the campaign was not malicious in the sense that PETA did not intend to minimise the suffering of holocaust victims nor to violate their human dignity, they nevertheless concluded that the comparison was 'banalising', and that 'the Basic Law drew a clear distinction between human life and dignity on the one side and the interests of animal protection on the other'. The injunction was therefore justified on the basis that the 'content of the campaign affected the plaintiffs' personality rights. ${ }^{59}$

The ECtHR unanimously agreed. Though its judgment noted the particular context of Jews living in Germany and pointed out 'that courts in other jurisdictions might address similar matters in a different way', ${ }^{60}$ it accepted that the decision of the domestic courts was reasonable. In coming to that finding it agreed that the posters did not 'aim to debase the depicted concentration camp inmates, as the pictures merely implied that the suffering inflicted on the depicted humans and animals was equal. ${ }^{61}$ Nevertheless, and revealingly, it characterised the treatment of the concentration camp victims as 'instrumentalisation' in the 'interests of animal protection'. ${ }^{62}$ This theme was taken up_-and taken further-by Judge Zupančič in a concurring opinion joined by Judge Spielmann. There they asked

\footnotetext{
${ }^{57}$ ECHR, PETA Deutschland v. Germany (n. 1), para. 7.

${ }^{58}$ Ibid., para. 11.

${ }^{59}$ Ibid., paras. 17-18; see also Landgericht Berlin, Judgment of 18 March 2004, 27 O 207/04; Landgericht Berlin 22 April 2004, 27 O 207/04; Kammergericht, Judgment of 30 July 2004, 9 U 118/04; Kammergericht, Judgment of 27 August 2004, 9 U 118/04; Landesgericht Berlin, Judgment of 2 December 2004, 27 O 676/04; Kammergericht, Judgment of 25 November 2005, 9 U 15/05; Bundesverfassungsgericht, Judgment of 20 February 2009, 1 BvR 2266/04, 1 BvR 2620/05.

${ }^{60}$ ECHR, PETA Deutschland v. Germany (n. 1), para. 49.

${ }^{61}$ Ibid., para. 48.

${ }^{62}$ Ibid.
} 
[W] hether reasonable [people] could indeed or could not differ on the utterly disgraceful and unacceptable comparison between pigs on the one hand and the inmates of Auschwitz or some other concentration camp, on the other hand. ${ }^{63}$

[W] hen human beings in their utter suffering and indignity are, as here, compared to hens and pigs for the lesser purpose of protecting otherwise legitimate advancement of animal rights, we are no longer in the position to maintain that the human beings seen in these pictures are treated as an end in themselves. [...] If their image is so instrumentalised, little is left of their human dignity[.] ${ }^{64}$

Though these statements were seemingly too strongly put for the majority of the Court, the underlying reasoning appears to be the same. Certainly, Judge Zupančič is correct in pointing out that using the picture of the concentration camp victims simply as a comparator does not accord with the Kantian imperative that individuals be treated as ends in themselves, but it is worth pausing to consider whether a comparison of holocaust victims with-for example-victims of modern-day international crimes would have attracted the same condemnation. That would be no less of an instrumentalisation, but it seems clear that for Judges Zupančič and Spielmann (even if not for the domestic courts) the context of the comparison was a significant part of the harm the campaign committed. It may be that it was not instrumentalisation per se that was objectionable, but rather instrumentalisation of the human in service of the animal.

Nor is that conclusion - or its counterpart that the animal may be instrumentalised in service of the human-a surprising position for the Court to reach. It is almost unnecessary to say, for example, that the Court has no objection in principle to the use of animals as game, ${ }^{65}$ for medical experimentation, ${ }^{66}$ or for food. ${ }^{67}$ In some circumstances animal welfare concerns take second place to facilitation of religious practice. ${ }^{6}$ Given a direct conflict between animal life and human safety and wellbeing the Court unsurprisingly privileges human safety. ${ }^{69}$ The Court should

\footnotetext{
${ }^{63}$ Concurring Opinion of Judge Zupančič, Joined by Judge Spielmann, ECHR, PETA Deutschland v. Germany (n. 1), 16-18, at para. 5.

${ }^{64}$ Ibid., paras. 14-15. A similar argument in the academic sphere is made by Leslie Pickering Francis and Richard Norman, who argue that the term "animal liberation" "has the effect of trivializing [...] real liberation movements, putting them on a level with what cannot but appear as a bizarre exaggeration': Francis/Norman, 'Some Animals are More Equal than Others' 1978, 527. Kymlicka and Donaldson respond powerfully to such arguments: Kymlicka/Donaldson, 'Animal Rights, Multiculturalism, and the Left' 2014, 116-135. A historical analysis of the human/animal dichotomy is given by Anna Becker in her contribution to this volume.

${ }^{65}$ See ECHR, Chassagnou v. France (n. 1), and the cases that followed it.

${ }^{66} \mathrm{ECHR}$, Tierbefreier e.V. v. Germany (n. 1).

${ }^{67}$ ECHR Cha'are Shalom (n. 1); ECHR, Jakóbski v. Poland (n. 1).

${ }^{68}$ ECHR Cha'are Shalom (n. 1). Importantly, though, the Court held here that the state retained a margin of appreciation to decide on what basis permits to slaughter animals in accordance with religious requirements (in this case the strict requirements to qualify as glatt kosher) would be granted in order to, among other things, enable it to protect public health and animal welfare (paras. 76-77, 84). Provided that meat prepared according to the requirements of one's religion is available, article 9 does not extend to a right to slaughter one's meat oneself (paras. 80-82).

${ }^{69}$ ECHR, Stoicescu v. Romania (n. 1).
} 
not be criticised for these positions: to adopt the contrary finding on any of these points would take the Court radically beyond the understanding of the rights involved prevalent in the Council of Europe states, and thus well beyond its remit to 'interpret[the Convention] in the light of present-day conditions and of the ideas prevailing in democratic States'. ${ }^{70}$ The Court generally cites Tyrer $v$. UK as the source of this principle, which casts the Convention as a 'living instrument'. ${ }^{71}$ Although this means that standards of protection may develop, ${ }^{72}$ the Court has also explicitly arrived at the corollary conclusion that it should not go beyond these evolving standards. ${ }^{73}$ It is therefore not at liberty to find that hunting, eating or experimenting on animals is improper even if it were inclined to do so: every Council of Europe state accepts these practices within certain limits, and nor is there a consensus even among animal activists and scholars on their (im)propriety. ${ }^{74}$

Although the obligation-both precedential and of prudence-not to stray beyond the understanding of the Convention rights among the states forecloses certain radical steps in using the ECHR to protect animal welfare, the 'living instrument' formulation also offers the promise that future developments may be incorporated into the Convention's protections. Judge Pinto de Albuquerque's separate opinion in Hermann v. Germany in 2012 gives an indication of the mechanism through which this could take place. ${ }^{75}$ Animals, Pinto de Albuquerque argued, are protected under the ECHR in two ways. First, they may be property within the definition of article 1 of Protocol $1 .^{76}$ More importantly, they may be protected 'as beings in themselves [. . .] as part of a healthy, balanced and sustainable environment', ${ }^{77}$ under the umbrella of the article 8 obligation to 'avoid acts and activities that could have detrimental consequences for public health and the environment'. ${ }^{78}$ Pinto de Albuquerque finds "clear and uncontested evidence of a continuing international trend" in favour of the protection of animal life and welfare

\footnotetext{
${ }^{70}$ ECHR, Khamtokhu and Aksenchik v. Russia, Grand Chamber Judgment of 24 January 2017, Application Nos. 60367/08 and 961/11, para. 73 [references omitted].

${ }^{71}$ ECHR, Tyrer v. UK, Chamber Judgment of 25 April 1978, Application No. 5856/72, para. 31.

${ }^{72}$ ECHR, Khamtokhu and Aksenchik (n. 70), para. 73; see also ECHR, Selmoui v. France, Grand Chamber Judgment of 28 July 1999, Application No. 25803/94, para. 101.

${ }^{73}$ ECHR, Khamtokhu and Aksenchik (n. 70), para. 74

${ }^{74}$ For different perspectives on these questions see Cochrane, Animal Rights without Liberation: Applied Ethics and Human Obligations 2012; Taylor, 'Whiter Rights? Animal Rights and the Rise of New Welfarism' 1999, 27-41; Harrop, 'Climate Change, Conservation and the Place for Wild Animal Welfare in International Law' 2011, 441-462. Outside academia, compare the remit of the Animal Welfare Council (http://www.animalwelfarecouncil.org/?page_id=9), with PETA (https:// www.peta.org/about-peta/faq/what-is-the-difference-between-animal-rights-and-animal-welfare/).

${ }^{75}$ Partly Concurring and Partly Dissenting Opinion of Judge Pinto de Albuquerque, ECHR, Herrmann v. Germany (n. 1), 32-49. Similar themes were also discussed in the earlier Partly Dissenting Opinion of Judge Zagrebelsky, ECHR, Kyrtatos v. Greece (n. 1), 14-15.

${ }^{76}$ Ibid., 32.

${ }^{77}$ Ibid.

${ }^{78}$ Ibid., 33 [references omitted].
} 
[which] is reflected in the application of the Convention. ${ }^{, 79} \mathrm{He}$ argues that the Court should reject both the 'commodification' of animals and extensive conceptions of human-like animal personality, instead embracing a 'qualified speciesism which builds upon a responsible anthropocentrism. ${ }^{80} \mathrm{He}$ concludes that recognising the moral differences between humans and animals 'does not prevent us from acknowledging the $[\ldots]$ existence of basic comparable interests between humans and other animals and therefore the need to safeguard certain 'animal rights', metaphorically speaking, in a similar way to human rights. ${ }^{81}$ The mechanism through which this should be achieved is not the grant of legal personality to animals to raise claims before the Court (nor upon human 'representatives' to do so), ${ }^{82}$ but rather through the obligation of states to realise the human right to a healthy environment. ${ }^{83}$

While there is much here that is attractive, there remain problems with the application of the approach Pinto de Albuquerque proposes, and flaws in the approach itself. To begin with application, it is increasingly accepted that a healthy environment is an aspect of human rights. ${ }^{84}$ As yet, however, it is unclear whether the ECHR has the potential adequately to integrate this idea into its provisions. Prima facie, environmental harms are more closely connected to the protection of social and economic rights than the primarily civil and political rights of the ECHR. The disconnect is clear in Kyrtatos v. Greece, in which the Court was asked to decide that the illegal destruction of a wetland habitat next to the applicants' house was a violation of article 8 . The Court chose not to do so, holding that the applicants had not demonstrated that the effect of the environmental degradation on them 'directly affect[ed] their own rights under article 8 . ${ }^{85}$ The Court reached that conclusion by six votes to one, with Judge Zagrebelsky the only dissenter. It can be speculated then, that although it would be possible for environmental degradation to have sufficiently negative effects to amount to a breach of article 8 , such a finding is likely to be made only where there is a measureable negative effect on individuals' health or some other equally weighty aspect of their lives. By contrast, and despite that it materially affected their quality of life, 'the Court

\footnotetext{
${ }^{79}$ Ibid., 36, citing ECHR, Goodwin v. UK (n. 50), para. 85.

${ }^{80}$ Opinion of Pinto de Albuquerque (n. 75), 37 [emphasis and references omitted].

${ }^{81}$ Ibid., 37 [references omitted].

${ }^{82}$ The ability of animals to appear as "persons" before the courts is discussed below, at note 89 .

${ }^{83}$ Opinion of Pinto de Albuquerque (n. 75), 38.

${ }^{84}$ See, for example, the recent framework principles prepared by John Knox in his capacity as special rapporteur: Human Rights Council, 'Report of the Special Rapporteur on the Issue of Human Rights Obligations relating to the Enjoyment of a Safe, Clean, Healthy and Sustainable Environment', 24 January 2018, UN Document No. A/HRC/37/59. Knox suggests two parallel provisions as his first and second framework principles, that '[s]tates should ensure a safe, clean, healthy and sustainable environment in order to respect, protect and fulfil human rights', and that ' $[\mathrm{s}]$ tates should respect, protect and fulfil human rights in order to ensure a safe, clean, healthy and sustainable environment' (page 7).

${ }^{85}$ ECHR, Kyrtatos v. Greece (n. 1), para. 53.
} 
[did not] accept that the interference with the conditions of animal life in the swamp constitute[d] an attack on the private or family life of the applicants. ${ }^{86}$ If the precedent set in Kyrtatos stands, then, a harm to animal life and the wider environment will have to produce very substantial negative impacts on individuals before it will be possible to assimilate these harms under article $8 .^{87}$

Yet there are potential problems, too, with the idea of responsible anthropocentricism as a theoretical lens through which to interpret the ECHR in ways conducive to the protection of animal welfare, in that it remains-obviouslyanthropocentric. $^{88}$ Of course, one could hardly expect the ECtHR to move to a position beyond 'responsible anthropocentricism' without alteration of the Convention or a substantial leap in its interpretation. Such an interpretive move would, in theory, be possible: indeed, there is nothing in the text of the convention that would prevent it from being extended to apply to (some) animals. Despite its title (Convention for the Protection of Human Rights; Convention de sauvegarde des droits de l'homme), the personal scope of the Convention as defined by its first article does not refer to 'humans' but rather to 'everyone' and 'toute personne', both terms which seem amenable to a legal rather than scientific definition. Nevertheless, it remains to be seen whether the Court is able to go this far, ${ }^{89}$ and that uncertainty serves to make

\footnotetext{
${ }^{86}$ Ibid.

${ }^{87}$ This conclusion is broadly supported by Natalia Kobylarz's study of the Court's case-law on wider aspects of environmental protection. While the Court has been able to provide relief under the ECHR in a number of environmental damage scenarios, it remains necessary to show an immediate link to a concrete harm. See Natalia Kobylarz, 'The European Court of Human Rights: An Underrated Forum for Environmental Litigation', in European Environmental Law Forum, Sustainable Management of Natural Resources - Legal Approaches and Instruments (forthcoming), available at: https://ssrn.com/abstract $=3178983$, accessed 30/05/2018.

${ }^{88}$ On this idea see Redgwell, 'Life, The Universe And Everything' 1996, 71-87, esp. 75-79; Shelton, 'Environmental Rights' 2001, 190; Bulto, 'The Environment and Human Rights' 2014, 1015-1030; de Lucia, 'Beyond Anthropocentricism and Egocentrism', 2017, esp. 184-188.

${ }^{89}$ Note, for example, the Court's decision to deny jurisdiction ratione personae over the application in Stibbe v. Austria, a case brought by an animal rights activist on behalf of a chimpanzee known as Matthis Pan. Stibbe sought to be appointed the legal guardian of Matthis Pan, but her application was denied by the Austrian courts on the basis that only humans can have guardians. Her appeal to the ECtHR was declared inadmissible on the basis that " $[\mathrm{t}]$ he applicant cannot [...] claim to have herself been a victim of the violation in accordance with article 34 of the Convention. The complaint is therefore not in accordance with the personal scope of the Convention under article 35 paragraph 3': Letter from A. Wampach, Deputy Registrar for the First Section, in the matter of ECHR, Stibbe v. Austria, 22 January 2010, Reference No. ECHR-LGer11.0R(CD8); IF/IW/tpe; Application No. 26188/08 [my translation]. Jurisdiction ratione personae, clearly, will be an obstacle to cases of this kind being heard before the ECtHR. This may be contrasted to the now-famous Orangutána Sandra decision before the courts of Argentina, in which it was decided animals may be the subject of rights: 'Based on a dynamic rather than a static legal interpretation, it is necessary to accord the animal the status of a rights-holder. Non-human subjects (animals) are bearers of rights, and therefore their protection is required within the corresponding jurisdiction': Camera Federal de Casación Penal, Orangutána Sandra, Judgment of 18 December 2014, LEX No. CCC 68831/2014/ CFC1, para. 2. [I thank Dr Pedro Villarreal for his assistance interpreting the judgment and preparing this translation.] Similar decisions were handed down in 2016 in another Argentinian
} 
the anthropocentrism problem and its study more urgent. If anthropocentricism is a barrier to the formulation of meaningful principles to undergird animal welfare (let alone animal rights), then one must necessarily conclude that the human rights framework cannot contribute to the development of global animal law. ${ }^{90}$ That question has been discussed elsewhere (and is taken up in several of the other contributions to this volume), and is too large and complex adequately to be discussed here. ${ }^{91}$ However, in the present author's opinion, this proposition is not correct. On the contrary, human rights law can meaningfully contribute to the development of global animal law. Though it may be that global animal law will eventually need to separate itself from human rights law if it is to realise its potential, in its early stages of development there are numerous opportunities for synergistic interactions with frameworks such as the ECHR.

This is the argument forcefully and convincingly made by Connor Gearty in the wider context of environmental protection. ${ }^{92}$ Gearty begins by acknowledging that environmental concerns (and, for our purposes, animal welfare and rights) do not sit easily alongside the human rights framework's proud anthropocentricism:

The subject of human rights is, as it declares for all to see in the way that it describes itself, a field that is concerned not only with humans but also with the rights that flow from being human, rather than from being anything else[.] $]^{93}$

Human rights law exemplifies and makes explicit a sin Anne Peters identifies more generally, that 'the law as it stands mirrors and reifies a human-animal divide'. ${ }^{94}$ Yet

case (Tercer Juzgado de Garantías de Mendoza, Chimpanzee 'Cecilia', Judgment of 3 November 2016, No. P-72.254/15), and by the Colombian Supreme Court in 2017, granting habeas corpus in favour of a spectacled bear: Corte Suprema de Justicia de Colombia, Judgment of 26 July 2017, AHC4806-2017, Radicación no. 17001-22-13-000-2017-00468-02. In the common law world such cases have to date been raised only in the USA, and as yet without great success. In the most recent development (at time of writing), application to appeal to the New York Court of Appeals was denied on 5 April 2018 in joined cases submitted on behalf of two chimpanzees, in which a writ of habeas corpus was denied at first instance: State of New York Court of Appeals, In re the Nonhuman Rights Project, inc., on behalf of Tommv v. Patrick C. Lavery and In re the Nonhuman Rights Project, inc., on behalf of Kiko v. Carmen Presti et al., Judgment of 8 May 2018, unreported, Motion No. 2018-268.

${ }^{90}$ And there are many who argue that it should not. See, for example, Elder, 'Legal Rights for Nature - The Wrong Answer to the Right Question' 1984, 285-295; Livingston, 'Rightness or Rights?' 1984, 309-321; Machan, 'Do Animals Have Rights?' 1991, 163-173; Merrills, 'Environmental Rights' 2007, 672.

${ }^{91}$ See, in particular, Peters, 'Liberté, Égalité, Animalité: Human-Animal Comparisons in Law' 2016b, 39-44 et seq.; Gearty, 'Do Human Rights Help or Hinder Environmental Protection' 2010, 7-22; and further Plass, 'Exploring Animal Rights as an Imperative for Human Welfare' 2010, 403-430; Keim/Sosnowski, 'Human Rights v Animal Rights: Mutually Exclusive or Complementary Causes' 2012, 78-83. An intriguing (but, in the author's view, ultimately ill-directed) inversion of this debate is Shikubu, 'Work like a Dog' 2014, 44-65.

${ }^{92}$ Gearty, 'Human Rights and Environmental Protection' 2010.

${ }^{93}$ Ibid., 7. [References omitted]. A similar argument is made by Knox, 'Climate Ethics and Human Rights' 2014, 22-34; but compare the problematisation of this aspect of human rights discourse in Blouin Genest/Paquerot, 'Environmental Human Rights as a Battlefield' 2016, 132-154.

${ }^{94}$ Peters, 'Liberté, Égalité, Animalité' 2016a, 26. 
Gearty argues that human rights has the potential to support environmental protection both through the protection of environmental activism ('protecting the messenger'), ${ }^{95}$ and by offering a vocabulary of empowerment that activists can use.

It speaks meaningfully across the whole spectrum of a community, from the weak across to the powerful, deploying the convictions of the latter-rooted in the battles of the past- to force recognition of the need for similar struggles today. [...] This chameleonism is often a source of frustration for sure, but it is what gives the idea of human rights the power that it undeniably enjoys in the world today. ${ }^{96}$

Though human rights are intrinsically anthropocentric, the human rights project is a legally-embedded socio-linguistic mobilisation of empathy for the other. ${ }^{97}$ Using the language of human rights carries with it the historical experience of the manifold struggles for justice that have been fought under its banner. Embedded in the framework are the memories of many claims once bitterly contested as radical oppositions to an entrenched power-structure which have succeeded in breaking into the mainstream consciousness, have overturned centuries of social practice, or have been codified as a minimum standard of positive morality in international declarations and conventions. The language, experience, and historical legitimacy-claim of human rights can be powerful tools in the campaign for animal (and wider environmental) rights, notwithstanding the inevitable friction between zoo- and anthropos-centrism.

\section{Final Thoughts}

Although that friction is more pronounced (and the radical discourse more constrained) within human rights viewed as a legal framework rather than a sociopolitical project, nevertheless many of the same arguments hold true. There are barriers to the direct treatment of animal concerns by human rights fora as a result of personal and material limitations on their scope of jurisdiction, but the case-law of the ECtHR demonstrates that there remain opportunities to bring animal concerns under the umbrella of human welfare. This does, it is true, raise moral questions, in particular the 'speaking for the other' problem', as Catharine MacKinnon has

\footnotetext{
${ }^{95}$ Gearty, 'Human Rights and Environmental Protection' 2010, 15-18.

${ }^{96}$ Ibid., 21; for a similar argument grounded in the concept of dignity see Kotzmann/Seery, 'Dignity in International Human Rights Law' 2017, 1-41.

${ }^{97}$ Gearty, 'Human Rights and Environmental Protection' 2010, 22. The significance of empathy is also persuasively emphasised by Peters, who notes not only the transformative power of empathy on discourses and societies (39-42), but also the potential for definitions to structure empathic reactions. She begins by recalling the hideous nineteenth and twentieth century practice of displaying people of non-European origin as zoo exhibits, and notes that '[t]he "primitives" were relegated to the animal side of an imagined boundary': Peters, 'Liberté, Égalité, Animalité' 2016a, 25-26; see also Peters, 'Introduction: Animal Law - A Paradigm Change' 2015, 17-18. For an examination of empathy as a basis for distinctively human rights see Robinson, 'Biological Foundations of Human Rights' 2013, 54-81.
} 
pointed out. ${ }^{98}$ Animal law remains human law, and it aspires towards a human interpretation of what 'animal welfare' looks like. Yet though the interpretative divide is deeper, Peters is clearly correct to ask where the differences lie between speaking for animals and speaking for humans who lack legal capacity (Peters' example is children). ${ }^{99}$ Arguably in the case of animals the situation is more problematic: where we raise children's concerns before Courts we do so for the benefit of the children involved, while animal rights at present flow from human rights only as a corollary of human concerns. The former is a case of speaking for, with all the moral difficulties that flow from that; the latter is an example of instrumentalisation. Yet there is also a zone of confluence, ${ }^{100}$ in which human and animal wellbeing and rights coincide insofar as it can be demonstrated that protecting the one benefits the other. ${ }^{101}$ Peters uses the phrase 'liberté, égalité, animalité' as 'a reminder that humans need legal protection not least on account of their animal nature, their physical vulnerability and their "nakedness", which they share with all other animals." 102 It is indeed a salutary reminder that the human/ animal divide is bridged in many respects, including the 'vital interests' of both groups. ${ }^{103}$ Articulating those confluences within the language of the ECHR and other human rights frameworks has the potential to catalyse the development of animal welfare as a sub-genre of the international human rights story, as well as to provide norms, ideas and impetuses which will cross into other jurisdictions and disciplines, and scholars should now take up this task. It is in these interactions that global animal law is growing and will continue to grow, ${ }^{104}$ and this brief

\footnotetext{
${ }^{98}$ MacKinnon, 'Of Mice and Men: A Feminist Fragment on Animal Rights' 2004, 270.

${ }^{99}$ Peters, 'Liberté, Égalité, Animalité' 2016a, 48.

${ }^{100}$ This idea is similar to Bulto's substantive regime complementarity: Bulto, 'Environment' 2014, 1025-1028.

${ }^{101} \mathrm{An}$ example of such an approach in practice can be seen in the Court's decision on admissibility in Friend and Others $v U K$ (n. 1). In that case, a challenge to the UK ban on hunting wild mammals with dogs, the Court first ruled that the Convention articles claimed by the applicants were not engaged, before noting (in particular in relation to article 11) that "the measures served the legitimate aim of (...) "the protection of ... morals", in the sense that they were designed to eliminate the hunting and killing of animals for sport in a manner which the legislature judged to cause suffering and to be morally and ethically objectionable' (at 18). The Court thus found that had the convention rights been engaged, the limitation would nevertheless have fallen within the State's margin of appreciation. Though at best indicative, as no full examination was undertaken, the admissibility decision shows one way in which the interests of animals can condition human rights - in this case as a limitation, elsewhere through a zone of confluence approach.

${ }^{102}$ Peters, 'Liberté, Égalité, Animalité' 2016a, 53; citing Saskia Stucki, 'Sind die Menschenrechte in Zukunft noch Menschen-Rechte?', Völkerrechtsblog, 13 May 2014, available at: http:// voelkerrechtsblog.com/category/sind-die-menschenrechte-in-zukunft-noch-menschen-rechte/.

${ }^{103}$ This idea I take from Mark Rowlands, Animals Like Us (London: Verso 2002), 125-136 et seq. Rowlands uses the term to refer to the interest all animals have in remaining alive, as well as the basic goods that enable them to do so. He argues that the non-vital interests of any (human or non-human) animal should not outweigh the vital interests of any other.

${ }^{104}$ Anne Peters, 'Global Animal Law: What it is and why we need it', Transnational Environmental Law 5(1) (2016b), 9-23, 20.
} 
examination of the ECtHR suggests that human rights law has a meaningful contribution to make to that process.

\section{References}

Blouin Genest, G., \& Paquerot, S. (2016). Environmental human rights as a Battlefield: A grammar of political confrontation. Journal of Human Rights and the Environment, 7, 132-154.

Bulto, T. S. (2014). The environment and human rights. In A. Mihr \& M. Gibney (Eds.), The SAGE handbook of human rights (Vol. II, pp. 1015-1030). London: Sage Publishing.

Çoban, A. R. (2004). Protection of property rights within the European Convention on Human Rights. Aldershot: Ashgate.

Cochrane, A. (2012). Animal rights without liberation: Applied ethics and human obligations. New York: Columbia University Press.

de Lucia, V. (2017). Beyond anthropocentricism and egocentrism: A biopolitical reading of environmental law. Journal of Human Rights and the Environment, 8(2), 181-202.

Elder, P. S. (1984). Legal rights for nature - the wrong answer to the right question. Osgoode Hall Law Journal, 22(2), 285-295.

Fenwick, H., Phillipson, G., \& Williams, A. (2017). Texts, cases and materials on public law and human rights (4th ed.). Abingdon: Routledge.

Gearty, C. (2010). Do human rights help or hinder environmental protection. Journal of Human Rights and the Environment, 1, 7-22.

Harrop, S. (2011). Climate change, conservation and the place for wild animal welfare in international law. Journal of Environmental Law, 23(3), 441-462.

Keim, S., \& Sosnowski, J. (2012). Human rights v animal rights: Mutually exclusive or complementary causes. Australian Animal Protection Law Journal, 8, 78-83.

Knox, J. (2014). Climate ethics and human rights. Journal of Human Rights and the Environment, 5 (Special Issue), 22-34.

Kobylarz, N. (forthcoming). The European Court of Human Rights: An underrated forum for environmental litigation. In European Environmental Law Forum, Sustainable Management of Natural Resources - Legal Approaches and Instruments. Available at: https://ssrn.com/ abstract $=3178983$

Kotzmann, J., \& Seery, C. (2017). Dignity in international human rights law: Potential applicability in relation to international recognition of animal rights. Michigan State International Law Review, 26(1), 1-41.

Kymlicka, W., \& Donaldson, S. (2014). Animal rights, multiculturalism, and the left. Journal of Social Philosophy, 45(1), 116-135.

Livingston, J. (1984). Rightness or rights? Osgoode Hall Law Journal, 22(2), 309-321.

Machan, T. (1991). Do animals have rights? Public Affairs Quarterly, 5(2), 163-173.

MacKinnon, C. (2004). Of mice and men: A feminist fragment on animal rights. In C. Sunstein \& M. Nussbaum (Eds.), Animal rights: Current debates and new directions (pp. 263-276). Oxford: OUP.

Merrills, J. (2007). Environmental rights. In D. Bodansky, J. Brunnée, \& E. Hey (Eds.), The Oxford handbook of international environmental law (pp. 663-680). Oxford: OUP.

Peters, A. (2015). Introduction: Animal law - a paradigm change. In A. Peters, S. Stucki, \& L. Boscardin (Eds.), Animal law: Reform or revolution (pp. 15-32). Zürich: Schulthess.

Peters, A. (2016a). Liberté, Égalité, Animalité: Human-Animal Comparisons in Law. Transnational Environmental Law, 5, 25-53.

Peters, A. (2016b). Global animal law: What it is and why we need it. Transnational Environmental Law, 5(1), 9-23. 
Plass, S. A. (2010). Exploring animal rights as an imperative for human welfare. West Virginia Law Review, 112, 403-430.

Redgwell, C. (1996). Life, the universe and everything: A critique of anthropocentric rights. In A. Boyle \& M. Anderson (Eds.), Human rights approaches to environmental protection (pp. 71-87). Oxford: Clarendon Press.

Robinson, C. (2013). Biological foundations of human rights. In D. Shelton (Ed.), The Oxford handbook of international human rights law (pp. 54-81). Oxford: OUP.

Rowlands, M. (2002). Animals like us. London: Verso.

Shelton, D. (2001). Environmental Rights. In P. Alston (Ed.), Peoples' rights (pp. 185-258). Oxford: OUP.

Shikubu, M. (2014). Work like a dog: Expanding animal cruelty statutes to gain human rights for migrant farmworkers in the US. National Lawyers Guild Review, 71, 44-65.

Stucki, S. (2014, May 13). Sind die Menschenrechte in Zukunft noch Menschen-Rechte?. Völkerrechtsblog. Available at http://voelkerrechtsblog.com/category/sind-diemenschenrechte-in-zukunft-noch-menschen-rechte/

Taylor, N. (1999). Whiter rights? Animal rights and the rise of New Welfarism. Animal Issues, 3(1), $27-41$.

Tom Sparks is a senior research fellow at the Max Planck Institute for Comparative Public Law and International Law in Heidelberg, where he works in the research group of Professor Anne Peters. His research interests focus on public international law, international environmental law, the humanisation of law, and legal theory.

Open Access This chapter is licensed under the terms of the Creative Commons Attribution 4.0 International License (http://creativecommons.org/licenses/by/4.0/), which permits use, sharing, adaptation, distribution and reproduction in any medium or format, as long as you give appropriate credit to the original author(s) and the source, provide a link to the Creative Commons licence and indicate if changes were made.

The images or other third party material in this chapter are included in the chapter's Creative Commons licence, unless indicated otherwise in a credit line to the material. If material is not included in the chapter's Creative Commons licence and your intended use is not permitted by statutory regulation or exceeds the permitted use, you will need to obtain permission directly from the copyright holder. 